\title{
UPAYA BIMBINGAN PEMBINAAN KANTOR URUSAN AGAMA DALAM ANTISIPASI PERNIKAHAN TANPA MELALUI PENCATATAN KUA DI KECAMATAN PURWAHARJA KOTA BANJAR
}

\author{
Ahmad Gojin, Sofyan Ruskandar \\ Bimbingan Penyuluhan Islam STID Sirnarasa \\ ahmadgojin72@gmail.com
}

\begin{abstract}
ABSTRAK
Kebanyakan orang meyakini bahwa pernikahan tanpa melalui pencatatan KUA dianggap sah menurut hukum Islam apabila telah memenuhi rukun dan syarat-syaratnya, sekalipun pernikahan tersebut tidak dicatat di Kantor Urusan Agama (KUA). Akibat dari pemahaman tersebut timbullah dualism hukum yang ada di Negara Indonesia ini, yaitu disatu sisi perkawinan itu harus dicatatkan di Kantor Urusan Agama (KUA) dan disisi lain perkawinan tanpa dicatatpun tetap berlaku. Jika dilihat dari kenyataan yang ada, nikah dibawah tangan merupakan salah satu model perkawinan yang bermasalah dan cenderung mengutamakan kepentingan-kepentingan subjektif. Jenis penelitian ini adalah penelitian kualitatif yaitu penelitian yang memuat gambaran secara sistematis, faktual dan akurat mengenai data berupa ucapan atau tulisan dan perilaku yang dapat diamati didapat untuk mengungkap mengenai peran KUA dalam meminimalisir nikah tanpa pencatatan di Kecamatan Purwaharja. Tempat ataupun wilayah yang akan dijadikan lokasi dalam penelitian ini adalah Kantor Urusan Agama Kecamatan Purwaharja Kota Banjar dengan waktu penelitian yang diperlukan kurang lebih selama tiga bulan yakni dari bulan April sampai Juni 2018. Berdasarkan hasil Pemeriksaan dan Pencatatan Nikah dan Rujuk dengan peristiwa Nikah di Kecamatan Purwaharja pada tahun 20017 sebanyak 202 pernikahan. Selanjutnya berdasarkan catatan Pengadilan Agama dari bulan Januari sampai bulan Desember tahun 2017 masyarakat yang melakukan nikah tanpa pencatatan KUA berdasarkan alamat domisili pemohon itsbat nikah dengan jumlah yang sangat lumayan besar yaitu 17 orang dengan 4 Desa/Kelurahan yang berada dibawah naungan Kecamatan Purwaharja. Upaya yang dilakukan Kantor Urusan Agama kecamatan Purwaharja dalam meminalisir pernikahan dibawah tangan adalah: Pertama, melakukan penyuluhan-penyuluhan Pencatatan Pernikahan dan Keluarga Bahagia yang dilakukan oleh Badan Penasehat, Pembinaan dan Pelestarian Perkawinan (BP4) di Kantor Urusan Agama kepada calon pengantin dan wali. Kedua, melakukan sosialisasi tentang pentingnya pencatatan pernikahan dan dampak buruknya terhadap keluarga, ibu dan anak melalui seminar-seminar dan pengajian-pengajian yang diadakan oleh Departemen Agama melalui perwakilannya di kecamatan yang diselenggarakan di masyarakat. Ketiga, Kantor Urusan Agama saling bekerjasama dengan rekan kerjanya yang berada di setiap desa yaitu P3N (Pembantu Pegawai Pencatat Nikah/ Amil Desa) bersama staff aparatur desa melakukan penyuluhan-penyuluhan setiap 2 Bulan sekali kepada masyarakat yang diselenggarakan di Kantor Urusan Agama (KUA) Kecamatan dan juga sering diselenggarakan di balai desa sesuai dengan kesepakatan yang telah disepakati.
\end{abstract}

Kata kunci: Bimbingan, Kantor Urusan Agama, Pernikahan. 


\section{PENDAHULUAN}

Pembangunan nasional yang dilaksanakan oleh bangsa Indonesia pada hakekatnya merupakan pembangunan manusia seutuhnya dan pembangunan masyarakat Indonesia seluruhnya. Pembangunan nasional tersebut mencakup seluruh bidang kehidupan masyarakat, spiritual dan materil, fisik dan non fisik, dunia dan akhirat. Pembangunan tersebut mencakup pembinaan keluarga. Keluarga merupakan unit terkecil dalam masyarakat. Kesejahteraan, ketentraman dan keserasian, keluarga besar (bangsa) sangat tergantung kepada kesejahteraan, ketentraman dan keserasian keluarga. Keluarga terbentuk melalui perkawinan, ikatan antara dua orang yang berlainan jenis dengan tujuan membentuk keluarga. Ikatan suami isteri yang didasari niat ibadah ini diharapkan tumbuh berkembang menjadi keluarga (rumah tangga) bahagia kekal berdasarkan Ketuhanan Yang Maha Esa. Perkawinan merupakan sunnatullah yang umum dan berlaku pada semua makhluk-Nya, baik pada manusia, hewan maupun tumbuh-tumbuhan. Perkawinan adalah suatu cara yang dipilih oleh Allah sebagai jalan bagi makhluknya untuk berkembang biak dan melestarikan hidupnya. Perkawinan adalah suatu Akad antara seorang pria dan seorang wanita atas dasar kerelaan atau kesukaan kedua belah pihak, yang dilakukan oleh pihak lain (Wali) menurut sifat dan syarat yang telah ditetapkan Syara' untuk menghalalkan percampuran atas keduanya, sehingga satu sama lain saling membutuhkan menjadi sekutu sebagai teman hidup dalam rumah tangga.

Melengkapi kesempurnaan manusia sebagai makhluk yang mulia, Allah SWT telah membimbing manusia menuju fitrahnya. Diantara fitrah itu adalah kecenderungan hidup secara berpasang-pasangan. Dengan bahasa lain "manusia memiliki rasa ketertarikan terhadap lawan jenisnya yang dalam bahasa Al-Qur'an disebut Azwaj (berpasangpasangan).Perkawinan bukan hanya sekedar untuk menyalurkan nafsu seksual dengan cara yang sah, melainkan ia mengandung nilai-nilai yang luhur yang dicapai melalui perkawinan. Salah satu tujuan utama perkawinan adalah untuk memperoleh keturunan dan membangun rumah tangga. Rumah tangga itu sendiri merupakan suatu kumpulan dari masyarakat terkecil, yang mana di dalamnya terdiri dari pasangan suami, istri, anak-anak, mertua dan sebagainya. Terwujudnya suatu keluarga yang sah setelah didahului oleh Akad nikah atau perkawinan yang sesuai dengan ajaran Agama dan memenuhi beberapa syarat.

\section{KAJIAN PUSTAKA Pengertian Pernikahan}

Pernikahan adalah sunnatullah yang umum dan berlaku pada semua makhluk-Nya, baik pada manusia, hewan, maupun tumbuh-tumbuhan. Ia adalah suatu cara yang dipilih oleh Allah SWT, sebagai jalan bagi makhluk-Nya untuk berkembang biak dan melestarikan hidupnya.

Nikah berasal dari bahasa arab yaitu nikahun yang artinya adalah suatu akad yang menyebabkan kebolehan bergaul antara seorang laki-laki dengan perempuan, dan saling menolong antara keduanya. Dalam kamus bahasa Indonesia "asal kata dari perkawinan adalah "kawin" yang menurut arti bahasanya adalah membentuk suatu keluarga dengan lawan jenis, melakukan hubungan bersetubuh". Kata "nikah" sendiri sering digunakan untuk arti persetubuhan, juga untuk arti akad nikah".

Undang-Undang No.1 Tahun 1974 Pasal (1) dan (2) bahwa "perkawinan adalah ikatan lahir batin antara seorang pria dengan seorang wanita sebagai suami istri, dengan tujuan membentuk keluarga (rumah tangga) yang bahagia dan kekal berdasarkan ketuhanan yang Maha Esa".

Selain dari pada itu definisi yang dijelaskan oleh Undang-Undang No.1 tahun 1974 diatas, Kompilasi Hukum Islam di Indonesia juga memberikan definisi dan tujuan lain yang 
dicantumkan dalam Pasal 2 dan 3 yang tidak bertentangan dengan undang-undang perkawinan. Namun bersifat menambah penjelasan dengan rumusan sebagai berikut: "Perkawinan menurut hukum Islam adalah akad yang sangat kuat atau (mitsaqan ghalizhan) untuk mentaati perintah Allah dan melaksanakannya merupakan ibadah, Pasal 2), selanjutnya "tujuan perkawinan menurut Kompilasi Hukum Islam Pasal 3 adalah mewujudkan kehidupan rumah tangga yang sakinah mawaddah wa rahmah".

\section{Pernikahan Menurut Hukum Islam}

Pernikahan merupakan ikatan lahir batin antara seorang laki-laki dengan seorang perempuan sebagai suami istri dengan tujuan membentuk rumah tangga yang sakinah mawaddah wa rahmah (tentram, penuh cinta, dan kasih sayang) dan untuk mendapatkan keturunan yang shaleh dan shalihah.

Perkawinan atau pernikahan ialah akad antara seorang laki-laki dan perempuan atas dasar rela yang merubah status dan menghalalkan pergaulan antara laki-laki dan perempuan yang mana pada dasarnya bukan muhrim, serta melahirkan hak dan kewajiban menurut bukum Islam. Sebagaimana sabda Rasulullah SAW berikut: "Nikah itu termasuk sunnahku, barang siapa tidak mengamalkan sunnahku, maka bukan termasuk golonganku" (HR. Ibnu Majah).

\section{Pernikahan Menurut Hukum di Indonesia}

Perkawinan menurut kitab Undang-Undang Hukum Perdata Pasal 26, yang mengatakan bahwa perkawinan ialah pertalian yang sah antara seorang laki-laki dan seorang perempuan untuk waktu yang lama. KUH Perdata memandang perkawinan hanya dari hubungan keperdataan saja, yang berarti bahwa asalnya suatu perkawinan hanya ditentukan oleh pemenuhan syarat-syarat yang ditetapkan dalam Undang-Undang tersebut, sementara syaratsyarat serta pengaturan agama dikesampingkan. Perkawinan di anggap suatu lembaga yang terikat pada suatu pengakuan oleh Negara dan hanya sah bila dilakukan dihadapan pejabat berwenang (penguasa).

\section{Hukum Nikah}

Pernikahan adalah suatu akad atau perikatan untuk menghalalkan hubungan kelamin antara laki-laki dan perempuan dalam rangka mewujudkan kebahagiaan hidup berkeluarga yang diliputi rasa ketentraman serta kasih sayang dengan cara yang diridhoi oleh Allah SWT. Pelaksanaan perkawinan itu merupakan pelaksanaan hukum agama maka perlulah diingat bahwa dalam melaksanakan perkawinan itu oleh agama ditentukan unsur-unsurnya yang merupakan istilah hukumnya dan masing-masing rukun memerlukan syarat sahnya.

Pada dasarnya para fuqoha sepakat bahwa hukum menikah itu hukumnya wajib. Penyebabnya perselisihannya adalah syighot amar firman Allah "fankahu maa tooba lakum min annisai" ayat ini mengandung kemungkinan wajib, sunnah atau mubah tergantung kepada kemaslahatannya. Para ulama Maliki muta'akhirin berpendapat bahwa menikah itu wajib hukumnya bagi sebagian orang yang takut terjerumus akan zina, tidak mampu berpuasa. Sunnah bagi sebagian lainnya karena syahwatnya tidak terlalu bergejolak, ingin keturunan dan ada kemampuan.

\section{Rukun dan Syarat Sah Pernikahan}

Rukun dan syarat menentukan suatu perbuatan hukum, terutama yang menyangkut dengan sah atau tidaknya suatu perbuatan hukum itu. "Rukun dan syarat juga mengandung arti yang sama dan harus ada kedua-duanya dalam suaru perbuatan hukum tersebut, serta tidak boleh ditinggalkan salah satu dari keduanya".

Rukun yaitu sesuatu yang mesti ada yang menentukan sah dan tidaknya suatu pekerjaan (ibadah) dan sesuatu itu termasuk dalam rangkaian pekerjaan itu. Seperti membasuh muka untuk wudhu dan takbirotul ihram untuk shalat atau adanya calon pengantin laki-laki dan calon pengantin perempuan dalam perkawinan.

Syarat yaitu sesuatu yang mesti ada yang menentukan sah tidaknya suatu pekerjaan (ibadah) tetapi sesuatu itu tidak termasuk dalam rangkaian pekerjaan itu. Seperti menutup 
aurat untuk shalat dan calon pengantin laki-laki dan perempuan harus beragama Islam. Sedangkam sah yaitu suatu pekerjaan (ibadah) yang memenuhu rukun dan syarat.

\section{Rukun Perkawinan}

Rukun perkawinan adalah hakikat dari perkawinan itu sendiri, tanpa adanya salah satu rukun. Maka perkawinan tidak bias dilaksanakan karena rukun nikah merupakan bagian dari hakikat perkawinan dan wajib di penuhi pada saat berlangsungnya perkawinan. Rukun perkawinan itu terdiri atas:

a. Adanya calon suami dan istri yang akan melakukan perkawinan

b. Adanya wali nikah

c. Adanya dua orang saksi yang adil

d. Adanya ijab dan qobul yang diucapkan oleh wali atau wakilnya dari pihak wanita, dan dijawab oleh calon pengantin laki-laki.

\section{Syarat Sahnya Perkawinan}

Perkawinan merupakan salah satu ibadah dan memiliki syarat-syarat sebagaimana ibadah lainnya. Syarat-syarat yang dimaksud tersirat dalam Undang-Undang perkawinan dan Kompilasi Hukum Islam (KHI), syarat-syarat perkawinan merupakan dasar bagi sahnya perkawinan. Apabila syarat-syaratnya terpenuhi, maka perkawinan itu sah dan menimbulkan adanya segala hak dan kewajiban sebagai suami istri.

Pada garis besarnya syarat-syarat sahnya perkawinan calon mempelai pria adalah yaitu:

a. Beragam Islam

b. Laki-laki

c. Baligh

d. Berakal

e. Jelas orangnya

f. Dapat memberikan persetujuan

g. Tidak terdapat halangan perkawinan

\section{Syarat-syarat calon mempelai wanita adalah:}

a. Beragama Islam

b. Perempuan

c. Jelas orangnya

d. Dapat dimintai persetujuan

e. Tidak terdapat halangan perkawinan

Sedangkan menurut Kompilasi Hukum Islam (KHI) pada bab IV Pasal 14, menyebutkan bahwa rukun dan syarat perkawinan adalah sebagai berikut:
a. Calon suami
b. Calon istri
c. Wali nikah
d. Dua orang saksi, dan
e. Ijab dan Qobul

Adapun syarat yang merupakan suatu yang mesti ada dalam perkawinan dan merupakan salah satu bagian dari hakikat perkawinan tersebut. Misalnya saja syarat bahwa wali itu laki-laki, baligh, berakal (sehat jasmani dan rohani), seorang muslim, tidak sedang ihram, dan harus adil. Ini menjadi penting karena disini selain menjadi saksi pernikahan wali mempunyai posisi atau hak penuh untuk mengizinkan kedua mempelai tersebut boleh nikah atau tidak.

Dari uraian diatas menjelaskan bahwa akad nikah atau perkawinan yang tidak dapat memenuhi syarat dan rukunnya menjadikan perkawinan tersebut tidak sah menurut hukum.

\section{Tujuan dan Hikmah Pernikahan}


Tujuan perkawinan pada umumnya tergantung pada masing-masing individu yang akan melakukannya, karena lebih bersifat subjektif. Tetapi tujuan perkawinan menurut Agama Islam adalah untuk memenuhi petunjuk agama dalam rangka mendirikan keluarga yang cinta, kasih sayang, sejahtera dan bahagia. Harmonis dalam menggunakan hak dan kewajiban anggota keluarga. Sejahteranya untuk terciptanya ketenangan lahir dan batin disebabkan terpenuhinya kebutuhan hidup dan batinnya sehingga timbullah kebahagiaan, yakni kasih sayang antara anggota keluarga. "Selain itu dalam Kompilasi Hukum Islam (KHI) di pasal 3 menyebutkan bahwa perkawinan bertujuan untuk menghidupkan rumah tangga yang sakinah, mawaddah dan rahmah.”

\section{Prosedur Pencatatan Pernikahan}

Adapun prosedur atau tata cara pencatatan pernikahan di Kantor Urusan Agama (KUA) Kecamatan dapat dijelaskan sebagai berikut :

1) Persyaratan Umum

a. Calon pengantin.

b. Umur minimal : pria 19 tahun, Wanita 16 tahun.

c. Ada persetujuan kedua calon pengantin.

d. Tidak ada hubungan saudara yang dilarang Agama antara kedua calon pengantin.

e. Calon pengantin wanita sedang tidak terikat tali petkawinan dengan orang lain.

f. Bagi janda harus sudah habis masa iddahnya.

g. Wali dan saksi beragama Islam, umur minimal 19 tahun.

h. Calon pengantin, wali dan saksi sehat akalnya.

2) Persyaratan Administrasi

a. Foto copy KTP yang sah dan masih berlaku.

b. Foto copy KK (kartu keluarga) yang masih berlaku.

c. Foto copy Ijazah/Akte kelahiran/surat kenal lahir.

d. Foto copy buku nikah orang tua, bagi wanita.

e. Pas foto berwarna (latar biru) ukuran $2 \times 3$ sebanyak 4 lembar.

f. Surat Keterangan Model N1, N2, N4 ditandatangani kepala Desa/Kelurahan setempat.

g. Surat persetujuan kedua calon mempelai (Model N3).

h. Izin orang tua (Model N5) jika umur kurang 21 tahun.

i. Surat pernyataan jejaka/Perawan, bagi calon pengantin berumur 25 tahun keatas, bermaterai Rp.6000.

j. Rekomendasi pindah Nikah/Numpang Nikah bagi calon pengantin ari luar wilayah Kecamatan.

k. Izin Pengadilan Agama jika pria kurang dari 19 tahun dan wanita kurang dari 16 tahun.

1. Izin Pengadilan Agama bagi yang ingin berpoligami.

m. Rekomendasi Camat untuk pendaftaran Nikah kurang dari 10 hari.

n. Surat kematian suami/istri bagi janda/duda cerai mati dan model N6 ditandatangani Kepala Desa/Kelurahan.

o. Akta Cerai beserta Salinan Putusan/Penetapan dari Perngadilan yang mengeluarkan Akta Cerai.

p. Bukti imunisasi Tetanus Toxoid (TT) dari Puskesmas bagi wanita.

3) Pemberitahuan Kehendak Nikah

a. Kehendak Nikah diberitahukan oleh Wali/Calon Pengantin kepada KUA dengan membawa persyaratan yang ditemukan.

b. Mengisi Formulir Pendaftaran Nikah pada Lembar Model NB yang disediakan KUA.

c. Penulisan model NB menggunakan tinta hitam, huruf balok. 
d. Pendaftaran harus sudah di terima KUA sekurang-kurangnya 10 hari kerja sebelum akad nikah dilangsungkan.

e. Membayar biaya Pencatatan Nikah.

4) Pemeriksaan dan Pembinaan Calon Pengantin

Setelah dinyatakan telah memenuhi syarat maka calon pengantin dan wali nikahnya menandatangani Daftar Pemeriksaan Nikah. Setelah itu yang bersangkutan membayar biaya Administrasi Pencatatan Nikah sesuai dengan ketentuan yang berlaku. Untuk KUA Kecamatan Purwaharja biaya yang dikenakan kepada calon pengantin sebesar Rp.600.000,(Enam Ratus Ribu Rupiah) sesuai dengan peraturan Pemerintah No. 48 Tahun 2014, dan untuk pembayaran bisa di setorkan langsung ke KUA atau bisa melalui pihak Bank, hal ini berlaku untukakad yang dilakukan diluar Kantor KUA atau dirumah pihak Calon pengantin. Sedangkan apabila akadnya dilangsungkan di Kantor KUA dan pada jam kerja maka dikenakan biaya Rp.0,. Namun pada kenyataannya prosedural yang terjadi sangatlah kompleks, jadi calon pengantin yang ingin menikah mendaftarkan dahulu ke RT-RW-P3NKUA, hal ini membuat biaya yang dikeluarkan akibat birokrasi ini sangatlah membengkak, bahkan Ketua KUA mengatakan bahwa biaya yang di keluarkan bisa mencapai 300-400 ribu, ini kemudian yang membuat masyarakat enggan untuk mendaftarkan pernikahan mereka ke Kantor KUA.

Adapun pembinaan yang dilakukan oleh Kantor Urusan Agama (KUA) kepada para calon pengantin, yaitu :

a. Setelah Pendaftaran diterima oleh Kua, kedua calon pengantin dan wali nikah, melakukan pembinaan dan kursus calon pengantin.

b. Penghulu atau Kepala KUA melakukan pemeriksaan tentang ada tidaknya halangan untuk menikah, dan memberikan bimbingan keluarga sakinah dan tata cara ijab qobul.

c. Penghulu atau Kepala KUA dilarang melangsungkan atau membantu melangsungkan atau bahkan mencatat dan menyaksikan pernikahan yang tidak memenuhi persyaratan.

Setelah persyaratan dipenuhi oleh calon pengantin, PPN mengumumkan kehendak nikah pada papan pengumuman di KUA Kecamatan tempat akan dilangsungkan dan KUA Kecamatan tempat tinggal masing-masing calon mempelai. PPN tidak boleh melaksanakan akad nikah sebelum lampau 10 hari kerja sejak pengumuman, kecuali seperti yang diatur dalam pasal 3 ayat 3 Peraturan Pemerintah No. 9 Tahun 1975 yaitu apabila terdapat alasan yang sangat penting misalnya salah seorang calon mempelai akan segera bertugas keluar Negeri, maka dimungkinkan yang bersangkutan memohon dispensasi kepada Camat, selanjutnya Camat atas nama Wali atau Bupati memberi dispensasi.

5) Pelaksanaan Akad Nikah

Untuk pelaksanaan akad nikah ini bisa dilaksanakan:

a. Dibalai nikah atau Kantor KUA

b. Diluar balai nikah : rumah calon mempelai, masjid atau gedung dan lain-lain

Sebelum pelaksanaan upacara akad nikah, PPN atau penghulu terlebih dahulu mengecek ulang persyaratan nikah dan administrasinya kepada kedua calon pengantin dan walinya, untuk melengkapi kolom yang belum terisi pada waktu pemeriksaan awal dikantor atau ada perubahan data dari hasil pemeriksaan awal. Selain itu PPN/Penghulu menetapkan dua orang saksi yang memenuhi syarat sesaat sebelum akad nikah dilangsungkan, dianjurkan bagi ayah untuk meminta izin kepada anaknya yang masih gadis atau anak yang terlebih dahulu memberi izin kepada ayah atau wali, dan keharusan bagi ayah meminta izin kepada anaknya untuk menikahkan bila anak berstatus janda. Adapun prosedurnya yaitu:

a. Akad nikah dilangsungkan dihadapan penghulu atau petugaa KUA.

b. Ijab dilakukan oleh Wali Nikah sendiri. 
c. Wali nikah dapat mewakilkan Ijab kepada orang lain yang memenuhi persyaratan, atau kepada penghulu.

d. Akad nikah dilangsungkan di KUA (Balai Nikah).

e. Atas permintaan yang bersangkutan dan mendapatkan persetujuan dari kepala KUA, akad nikah dapat dilangsungkan diluar balai nikah.

f. Biaya pemanggilan, transportasi dan akomodasi Penghulu atau petugas KUA untuk menghadiri akad nikah diluar Balai Nikah dibebankan kepada yang mengundang.

6) Penyerahan Buku Nikah

Setelah mengucapkan Ijab Qobul selesai maka sang pengantin diberikan buku nikah. Namun jika ada kesalahan yang terdapat pada buku nikah seperti penulisan nama, tanggal lahir, tahun atau kesalahan penulis apapun maka disarankan untuk tidak dcoret sendiri tanpa izin, sebaiknya diserahkan kembali kepada KUA untuk perbaikan dan kemudian nanpti akan diperbaiki oleh KUA dan diserahkan kembali kepada pengantin.

7) Penolakan Kehendak Nikah

a. Kepala KUA diharuskan menolak kehendak nikah yang tidak memenuhi persyaratan.

b. Terhadap penolakan tersebut, yang bersangkutan dapat mengajukan keberatan kepada Pengadilan Agama.

\section{Pengertian Pernikahan tanpa melalui pencatatan KUA}

Menurut bahasa pernikahan tanpa melalui pencatatan KUA berarti pernikahan yang dilakukan secara sembunyi-sembunyi atau pernikahan yang dirahasiakan. Sedangkan menurut Islam, pernikahan tanpa melalui pencatatan KUA adalah pernikahan yang bisa dinyatakan sah secara Islam (apabila syarat dan rukunnya terpenuhi) namun tidak berkekuatan Islam.

Dalam pernikahan tanpa melalui pencatatan KUA, petugas pencatat nikah (KUA) tidak akan mencatat perkawinannya tersebut karena dianggap menyimpang dari UndangUndang yang berlaku. Akibatnya, pasangan yang menikah tidak akan mendapatkan surat nikah. Kalaupun mendapatkan surat nikah ada dua kemungkinan.

1. Surat nikah aspal (asli tapi palsu).

2. Petugas KUA berkolusi.

Faktor Terjadinya Pernikahan Tanpa Melalui Pencatatan KUA

Terdapat beberapa faktor yang melatar belakangi terjadinya pernikahan tanpa melalui pencatatan KUA,di antaranya yaitu

a. Tidak adanya kemampuan melaksanakan perkawinan secara Syariat, karena tidak bisa menyediakan tempat tinggal, disebabkan pengangguran dan tidak adanya kesempatan kerja layak.

b. Lemahnya benteng agama dan akidah serta kurangnya pembinaan keluarga untuk mengarahkan kepada akhlak yang mulia.

c. Terjadinya hubungan gelap yang mengakibatkan kehamilan.

d. Serta kurangnya ekonomi yang menjadi alasan mereka melakukan pernikahan tanpa melalui pencatatan KUA.

e.

\section{Status Hukum Pernikahan Tanpa Melalui Pencatatan KUA}

Menurut hukum Syariat bahwa sebuah perkawinan dipandang sah jika telah memenuhi rukun dan syarat perkawinan yang meliputi calon mempelai pria, calon mempelai wanita, wali mempelai wanita, dua orang saksi dan ijab qabul. Sedangkan menurut UndangUndang perkawinan selain memenuhi aturan syariat pernikahan harus dicatat oleh petugas pencatat perkawinan. Jika perkawinan sudah memenuhi kedua aturan tersebut maka perkawinan itu disebut legal wedding jika tidak tercatat maka disebut illegal wedding. 
Secara dogmatis, tidak ada nash dalam Al-Qur'an ataupun sunnah yang mengatur pencatatan untuk perkawinan, tetapi Al-Qur'an memberikan perhatian besar kepada pencatatn setiap transaksi utang dan jual beli. Semestinya jika dalam urusan muamalah seperti utang saja pencatatan diperintahkan, apalagi dalam perkawinan yang akan melahirkan hukum lain seperti hak pengasuhan anak, hak waris dan hak-hak lainnya.

\section{Dampak Positif dan Negatif Pernikahan Tanpa Melalui Pencatatan KUA}

Terdapat beberapa hal positif dan negatif dari terjadinya pernikahan tanpa melalui pencatatan KUA, diantaranya sebagai berikut :

a. Dampak Pofitif

1. Meminimalisasi adanya sex bebas, serta berkembangnya penyakit AIDS, HIV maupun penyakit kelamin yang lain.

2. Mengurangi Beban atau Tanggung jawab seorang wanita yang menjadi tulang punggung keluarganya.

b. Dampak Negatif

1. Tidak adanya kejelasan status isteri dan anak baik di mata Hukum Indonesia maupun di mata masyarakat sekitar.

2. Pelecehan sexual terhadap kaum hawa karena dianggap sebagai pelampiasan nafsu sesaat bagi kaum laki-laki.

3. Tidak memiliki buku nikah, tidak ada buku nikah tidak bisa mengurus KK, Akte Anak dan urusan lainnya.

Akibat Hukum Terjadinya Pernikahan tanpa melalui pencatatan KUA

Akibat hukum dari nikah tanpa melalui pencatatan KUA itu sendiri terdiri atas beberapa hal, diantaranya :

a. Sebagai seorang istri kita tidak dapat menuntut suami untuk memberikan nafkah baik lahir maupun batin.

b. Untuk hubungan keperdataan maupun tanggung jawab sebagai seorang suami sekaligus ayah terhadap anakpun tidak ada. "seperti nasib anak hasil dari pernikahan yang dianggap nikah tanpa melalui pencatatan KUA itu, akan terkatung-katung.Tidak bisa sekolah karena tidak punya akte kelahiran. Sedangkan, semua sekolah saat ini mensyaratkan akte kelahiran".

c. Dalam hal pewarisan, anak-anak yang lahir dari pernikahan tanpa melalui pencatatan KUA, akan sulit untuk menuntut haknya, karena tidak ada bukti yangmenunjang tentang adanya hubungan hukum antara anak tersebut dengan bapaknya atau antara isteri dengan suaminya tersebut.

\section{Kantor Urusan Agama}

Kementrian Agama adalah instansi yang menyelenggarakan tugas umum pemerintah dan pembangunan di bidang Agama. Kaitannya dengan tugas Kementrian Agama, dalam hal keluarga maupun dalam bermasyarakat yangbertujuan menciptakan manusia yang berkepribadian luhur, berkualitas tinggi, beriman dan bertaqwa kepada Tuhan Yang Maha Esa, kementrian Agama memerintahkan kepada Kantor Urusan Agama (KUA) yang merupakan bagian dari struktur Kementrian Agama untuk menyelenggarakan sebagian tugas umum pemerintahan dan pembangunan di bidang Agama.

Kantor Urusan Agama merupakan bagian paling bawah dari struktur kementrian Agama yang berhubungan langsung dalam satu wilayah kecamatan, sebagaimana yang ditegaskan dalam keputusan Menteri Agama No. 517/2001 bahwa Kantor Urusan Agaa bertugas melaksanakan sebagian tugas Kementrian Agama Kabupaten di bidang urusan Agama Islam di wilayah Kecamatan.

Tugas dan Wewenang 
Kantor Urusan Agama merupakan lembaga pemerintah yang berada di bawah naungan Kementrian Agama. Tugas dan wewenang Kantor Urusan Agama adalah melaksanakan tugas kantor Kementrian Agama kota dan Kabupaten yang di bidang urusan Agama Islam di wilayah Kecamatan, adapun tugas pokok Kantor Urusan Agama adalah seperti yang tercantum dalam BAB I Mengenai Kedudukan, Tugas Dan Fungsi Kantor Urusan Agama Berdasarkan Pasal 1-3 Undang-Undang Nomor 34 Tahun 2016 Tentang Organisasi Dan Tata Kerja Kantor Urusan Agama Kecamatan,yaitu :

Pasal 1:

1) Kantor Urusan Agama Kecamatan yang selanjutnya disingkat KUA Kecamatan adalah unit pelaksana teknis pada Kementrian Agama, berada dibawah dan bertanggung jawab kepada direktur jenderal Bimbingan Masyarakat Islam dan secara operasional dibina oleh Kepala Kantor Kementrian Agama Kabupaten Kota.

2) KUA Kecamatan berkedudukan di Kecamatan.

3) KUA Kecamatan dipimpin oleh Kepala.

Pasal 2: KUA Kecamatan mempunyai tugas melaksanakan layanan dan bimbingan masyarakat Islam di wilayah kerjanya.

Pasal 3: Dalam melaksanakan tugas sebagaimana dimaksud dalam Pasal 2, KUA Kecamatan menyelenggarakan fungsi :

1) Pelaksanaan pelayanan, pengawasan, pencatatan, dan pelaporan nikah dan rujuk.

2) Penyususnan statistik layanan dan bimbingan masyarakat Islam.

3) Pengelolaan sistem dokumentasi dan sistem informasi manejemen KUA Kecamatan.

4) Pelayanan bimbingan keluarga sakinah.

5) Pelayanan bimbingan kemasjidan.

6) Pelayanan bimbingan hisab rakyat dan pembinaan syariah.

7) Pelayanan bimbingan dan penerangan Agama Islam.

8) Pelayanan bimbingan zakat dan wakaf dan;

9) Pelaksanaan ketatausahaan dan kerumahtanggaan KUA Kecamatan. ${ }^{1}$

Adapun tugas dan wewenang pejabat dalam kantor urusan agama diantaranya sebagai berikut :

1) Kepala KUA:

a) Memimpin pelaksanaan tugas Kantor Urusan Agama menetapkan atau merumuskan Visi dan Misi, Kebijakan, Sasaran, Program dan Kegiatan Kantor Urusan Agama.

b) Membagi tugas, menggerakkan, mengarahkan, membimbing dan mengkoordinasikan pelaksanaan tugas Kantor Urusan Agama.

c) Melakukan pemantauan dan evaluasi terhadap pelaksanaan tugas bawahan.

d) Melakukan pelayanan dan bimbingan di bidang ketatausahaan.

e) Melakukan pelayanan dan bimbingan di bidang Nikah, Rujuk dan Keluarga Sakinah.

f) Melakukan usaha pengembangan dan peningkatan kualitas pelayanan di bidang pelaksanaan KUA.

g) Mempelajari dan menilai atau mengoreksi laporan pelaksanaan tugas di bawahan.

h) Melakukan kerjasama dengan instansi terkait.

2) Bidang Administrasi Nikah:

a) Meningkatkan pelayanan kepada masyarakat yang hendak melangsungkan pernikahan.

${ }^{1}$ Republik Indonesia, Undang-Undang Nomor 34 Tahun 2016 Tentang Organisasi Dan Tata Kerja Kantor Urusan Agama Kecamatan. Berita Negara Republik Indonesia Tahun 2016 Nomor 1252. 
b) Melaksanakan pemeriksaan terhadap surat-surat dan persyaratana dministrasi pernikahan.

c) Melaksanakan pengecekan terhadap registrasi akta nikah.

d) Melaksanakan penulisan akta nikah.

e) Memberikan penataran kepada calon suami istri sebelum melaksanakan nikah dan berumah tangga.

f) Mengadakan bimbingan dan penyuluhan kepada Pembantu Pegawai Pencatat Nikah atau Amil se-Kecamatan Purwaharja.

3) Bidan Kemasjidan

a) Menginventarisi jumlah dan perkembangan masjid, musholla dan langgar.

b) Melaksanakan bimbingan dan pembinaan terhadap remaja masjid.

c) Menerima, membukukan dan mengeluarkan serta mempertanggung jawabkan keuangan BKM dan P2A.

d) Mengikuti perkembangan pelaksanaan pembangunan tempat ibadah dan penyiaran Agama.

4) Bidang ZAWAIBSOS (Zakat, Wakaf, dan Ibadah sosial).

a. Melaksanakan bimbingan Zakat, Wakaf dan Ibadah Sosial.

b. Membukukan/mencatat tanah wakaf yang sudah selesai disertifikatkan.

c. Memelihara dan menertibkan arsip tanah wakaf.

d. Meningkatkan pelayanan kepada masyarakat dalam pelaksanaan Ibadah sosial.

5) Bidang Keuangan

a) Membuat laporan keuangan NR dan Rujuk

b) Menertibkan arsip keuangan.

c) Menyusun DUK/DIK

d) Membukukan dan menyetorkan uang NR ke pos atau Giro.

e) Menyalurkan dana bantuan dari NR kepada BKM. P2A, dan BP4.

6) Bidang Tata Usaha

a) Melaksanakan dan menangani surat menyurat.

b) Meningkatkan tertib administrasi, dokumen dan statistik.

c) Menyediakan pengadaan alat tulis kantor.

d) Membuat laporan bulanan, tri wulan, semester dan tahunan.

\section{METODE PENELITIAN}

Jenis penelitian ini adalah penelitian kualitatif yaitu penelitian yang memuat gambaran secara sistematis, faktual dan akurat mengenai fakta-fakta, sifat-sifat serta hubungan antar fenomena yang diselidiki dan menghasilkan data berupa ucapan atau tulisan dan perilaku yang dapat diamati didapat untuk mengungkap mengenai peran KUA dalam mengantisipasi nikah tanpa melalui pencatatan KUA di Kecamatan Purwaharja. Setelah data terkumpul kemudian disajikan dalam bentuk kata-kata atau kalimat yang kemudian ditarik suatu kesimpulan. Penelitian kualitatif berakar pada latar belakang alamiah sebagai keutuhan, mengandalkan manusia sebagai alat penelitian, menempatkan metode kualitatif, mengadakan analisis data secara induktif, mengarahkan sasaran penelitiannya pada usaha menemukan teori dasar-dasar bersifat deskriptif, lebih mementingkan proses dari pada hasil, membatasi studi dengan fokus, memiliki seperangkat kriteria untuk memeriksa keabsahan data rancangan. Penelitian bersifat sementara, dan hasil penelitiannya disepakati kedua belah pihak penelitian.

\section{HASIL DAN PEMBAHASAN}

Peran KUA Kecamatan Purwaharja dalam Mengantisipasi Nikah Tanpa Melalui Pencatatan

Dalam penelitian ini, peneliti menggunakan data yang diperoleh dari Pengadilan Agama Kota Banjar yang beralamat Desa Balokang Kecamatan Banjar Kota Banjar, Jawa 
Barat dalam masalah isbath nikah (Penetapan Perkawinan) karena faktor pemicu awalnya adalah dengan nikah tanpa melalui pencatatan KUA atau nikah tidak dicatat.

Berikut data pelaku masyarakat yang mengajukan isbath nikah:

Tabel 4.12

Pencatatan Isbath Nikah tahun 2017

\begin{tabular}{|l|l|l|l|l|l|}
\hline \multirow{2}{*}{ No } & \multirow{2}{*}{ Desa/Kelurahan } & Isbath & Cerai & \multirow{2}{*}{ Jumlah } & \multirow{2}{*}{ Ket } \\
\cline { 3 - 6 } & & I & C & & \\
\hline 1 & Purwaharja & 7 & - & 7 & \\
\hline 2 & Karangpanimbal & 3 & - & 3 & \\
\hline 3 & Raharja & 5 & - & 5 & \\
\hline 4 & Mekarharja & 2 & - & 2 & \\
\hline Jumlah & 17 & - & 17 & \\
\hline
\end{tabular}

(Penetapan Perkawinan) yang dicatat oleh Pengadilan Agama dari bulan Januari sampai bulan Desember tahun 2017 Kecamatan Purwaharja Kota Banjar yang melakukan nikah tanpa melalui pencatatan KUA (Nikah tidak dicatat) yang ingin mengajukan permohonan untuk melakukan itsbat Nikah di Pengadilan Agama. Karena masyarakat yang melakukan hal tersebut merasa banyak kendala yang dihadapi dalam melakukan segala kepentingan kepentingannya, terutama dalam bidang administrasi kenegaraan.

Data diatas juga telah menjelaskan dengan gamblang masyarakat yang melakukan nikah tanpa melalui pencatatan KUA berdasarkan alamat domisili pemohon itsbat nikah dengan jumlah yang sangat lumayan besar yaitu 17 orang dengan 4 Kecamatan yang berada dibawah naungan Kecamatan Purwaharja. Setelah penulis mendapatkan data tentang istbat nikah (penetapan nikah) dari Pengadilan Agama Kota Banjar, penulis langsung melanjutkan penelitian dengan melakukan wawancara kepada beberapa pihak, diantaranya kepala Kantor Urusan Agama KUA Kecamatan Purwaharja, dua orang masyarakat yang melakukan nikah tanpa melalui pencatatan KUA dan seorang staff yang bekerja di Pengadilan Agama.

Kepala Kantor Urusan Agama KUA Kecamatan Purwaharja yang bernama Bapak Dadang Hendra Utama S.Ag memang membenarkan adanya nikah tanpa melalui pencatatan KUA yang dilakukan oleh masyarakat yang ada didaerahnya, yang mana masyarakat melakukan hal tersebut dengan beberapa permasalahan diantaranya: pertama, faktor pendapatan perhari yang minim. Kedua, kurang tingginya kesadaran masyarakat akan pentingnya pecatatan pernikahan. Ketiga, faktor rendahnya pedidikan dan yang keempat faktor jarak yang ditempuh oleh masyarakat yang berada jauh diperbatasan desa antara Kota Banjar dengan Kabupaten Cianjur dan Kota Banjar dengan Kabupaten Cilacap.

Selanjutnya penulis melakukan wawancara dengan masyarakat yang melakukan nikah tanpa melalui pencatatan KUA, pertama warga yang bernama Solihin Bekerja sebagai buruh serta alasan (berkata) mengapa dia melakukan nikah tanpa melalui pencatatan KUA adalah "Boro-boro buat daftar biaya nikah ke KUA, buat makan setiap hari juga akang harus cari sana sini pekerjaan, soalnyakan akang mah cuma buruh tani yang penghasilannya tidak jelas dan tidak tetap, jadi akang nikahnya engga ke KUA sebab engga punya uang, terus kata orang-orang Nikah ke KUA mah ribet prosedurnya“.

Kemudian penulis wawancara kembali dengan masyarakat yang melakukan nikah tanpa melalui pencatatan KUA, yang kedua warga bernama IbuYati Bekerja sebagai Ibu Rumah Tangga serta alasan (berkata) mengapa dia melakukan nikah tanpa melalui pencatatan KUA adalah "jarak yang harus ditempuh ke Kantor Urusan Agama (KUA) kurang lebih memakan waktu sekitar satu jam perjalanan dengan akses yang yang kurang bagus (jalannya 
jelek) dan bibi tidak tahu menahu tentang pentingnya pencatatan nikah karena bibi hanya sekolah SD".

Terakhir, penulis melakukan wawancara dengan salah seorang staff yang bekerja di Pengadilan Agama Kota Banjar yang bernama Lia Rosliani, S.H.I., M.H memang membenarkan bahwa dari beberapa kecamatan yang ada di Kota Banjar sebanyak 4 kecamatan yang memiliki jumlah tertinggi dalam masalah permohonan istbat nikah adalah kecamatan Purwaharja yang mencapai sebanyak 17 orang pada tahun 2017. Adapun Peran Kantor Urusan Agama (KUA) Kecamatan Purwaharja yang memiliki jumlah tertinggi dalam hal masyarakat yang melakukan nikah tanpa melalui pencatatan KUA diantara kecamatankecamatan yang ada diwilayah Pemerintah Kota Banjar yaitu sekitar 17 Orang pada tahun 2018 dari data yang ada pada isbath nikah.

Hal-hal yang dilakukan Kantor Urusan Agama (KUA) Kecamatan Purwaharja dalam mengantisipasi nikah tanpa melalui pencatatan KUA, diantaranya adalah. Pertama, melakukan penyuluhan-penyuluhan Pencatatan Pernikahan dan Keluarga Bahagia yang dilakukan oleh Badan Penasehat, Pembinaan dan Pelestarian Perkawinan (BP4) di Kantor Urusan Agama kepada calon pengantin dan wali. Kedua, melakukan sosialisasi tentang pentingnya pencatatan pernikahan dan dampak buruknya terhadap keluarga, ibu dan anak melalui seminar-seminar dan pengajian-pengajian yang diadakan oleh Kementrian Agama melalui perwakilannya di kecamatan yang diselenggarakan di masyarakat. Ketiga, Kantor Urusan Agama saling bekerjasama dengan rekan kerjanya yang berada di setiap desa yaitu P3N (Pembantu Pegawai Pencatat Nikah/ Amil Desa) bersama staff aparatur desa melakukan penyuluhan-penyuluhan setiap 2 Bulan sekali kepada masyarakat yang diselenggarakan di Kantor Urusan Agama (KUA) Kecamatan dan juga sering diselenggarakan di balai desa sesuai dengan kesepakatan yang telah disepakati.

Kendala yang dihadapi oleh KUA Kecamatan Purwaharja dalam Mengantisipasi Nikah Tanpa Melalui Pencatatan

Setiap lembaga, instansi ataupun organisasi apapun jenisnya, baik itu berskala kecil ataupun besar dalam melaksanakan kegiatan untuk mencapai poin-poin penting dalam tujuannya pasti akan menemui berbagai hambatan, baik itu hambatan kecil maupun hambatan besar, baik berupa hambatan dari luar organisasi ataupun hambatan dari dalam organisasi sendiri. Dalam hal ini, bagaimanapun rapihnya suatu organisasi baik dalam struktur, pembagian tugas dan wewenang, serta kekuasaan tidak akan terlepas dari namanya suatu hambatan, karena organisasi adalah suatu system yang terbuka secara umum yang semua orang bisa ikut serta dan berkontribusi dalam melaksanakan suatu kegiatan yang pasti akan selalu berhubungan dengan orang banyak yang berada disekitar lingkungannya. Hambatan sekecil apapun bentuknya akan berpengaruh terhadap jalannya kegiatan yang akan dilaksanakan oleh organisasi tersebut. Hambatan sekecil apapun bentuknya yang ada dalam suatu organisasi, pasti akan mempengaruhi serta merugikan organisasi tersebut karena pelaksanaan kegiatan dalam rangka pencapaian tujuan organisasi akan terhambat. Mengakibatkan gagalnya pencapaian tujuan yang telah ditetapkan dalam dasar-dasar keorganisasiannya.

\section{KESIMPULAN}

1. Berdasarkan hasil Pemeriksaan dan Pencatatan Nikah dan Rujuk dengan peristiwa Nikah di Kecamatan Purwaharja pada tahun 20017 sebanyak 202 pernikahan. Selanjutnya berdasarkan catatan Pengadilan Agama dari bulan Januari sampai bulan Desember tahun 2017 masyarakat yang melakukan nikah tanpa melalui pencatatan KUA berdasarkan alamat domisili pemohon itsbat nikah dengan jumlah yang sangat lumayan besar yaitu 17 orang dengan 4 Desa/Kelurahan yang berada dibawah naungan Kecamatan Purwaharja. 
2. Upaya yang dilakukan Kantor Urusan Agama kecamatan Purwaharja dalam meminalisir pernikahan tanpa melalui pencatatan KUA adalah: Pertama, melakukan penyuluhanpenyuluhan Pencatatan Pernikahan dan Keluarga Bahagia yang dilakukan oleh Badan Penasehat, Pembinaan dan Pelestarian Perkawinan (BP4) di Kantor Urusan Agama kepada calon pengantin dan wali. Kedua, melakukan sosialisasi tentang pentingnya pencatatan pernikahan dan dampak buruknya terhadap keluarga, ibu dan anak melalui seminar-seminar dan pengajian-pengajian yang diadakan oleh Kementrian Agama melalui perwakilannya di kecamatan yang diselenggarakan di masyarakat. Ketiga, Kantor Urusan Agama saling bekerjasama dengan rekan kerjanya yang berada di setiap desa yaitu P3N (Pembantu Pegawai Pencatat Nikah/ Amil Desa) bersama staff aparatur desa melakukan penyuluhan-penyuluhan setiap 2 Bulan sekali kepada masyarakat yang diselenggarakan di Kantor Urusan Agama (KUA) Kecamatan dan juga sering diselenggarakan di balai desa sesuai dengan kesepakatan yang telah disepakati.

3. Kendala yang dihadapi Kantor KUA Kecamatan Purwaharja: Pertama, sangat terbatasnya pendapatan perekonomian masyarakat dalam kehidupan sehari-harinya. Sehingga mereka beralasan bahwa ketidakmampunya untuk membayar biaya administrasi yang ada di KUA serta biaya transportasi untuk menempuh jarak ke KUA. Kedua, adanya rasa malu dan malas bagi kedua keluarga dan mempelai untuk mendaftarkan diri atau mendaftarkan putra-putrinya untuk melakukan pernikahan di Kantor Urusan Agama setempat karena adanya rasa malas dan malu ini disebabkan karena status penikahan mereka yang ternyata berasal dari suatu "kecelakaan" yang telah mereka lakukan. Ketiga, kurangnya kesadaran dan pemahaman hukum di masyarakat masih banyak di antara masyarakat di Kecamatan Purwaharja. Keempat, rendahnya tingkat pendidikan yang dipelajari masyarakat yang ada di kecamatan Purwaharja dan yang terakhir adalah kurangnya tenaga Sumber Daya Manusia (SDM) yang bekerja di Kantor Urusan Agama (KUA) Purwaharja.

\section{Saran}

Dalam hal ini penulis ingin mengajukan beberapa saran yang diharapkan bisa bermanfaat:

1. Sebagai upaya pemberi semangat kepada KUA Kecamatan Purwaharja, apalagi yang bertugas melaksanakan pencatatannikah, rujuk, dan pengembangan keluarga sakinah, kiranya pemerintah yang berhubungan dan ada keterkaitannya dengan meningkatkan kesejahteraan KUA dalam upaya menangani permasalahan-permasalahan tentang maraknya pernikahan tanpa melalui pencatatan KUA.

2. Hendaknya mengembangkan fungsi dan peran KUA sehingga pengamanan sosial untuk memberikan dukungan terhadap keluarga agar bisa mengantisipasi terjadinya nikah tanpa melalui pencatatan KUA.

3. Hendaknya para pelaku nikah tanpa melalui pencatatan KUA memperhatikan saran dan bimbingan yang telah diberikan oleh pihak KUA Kecamatan Purwaharja supaya tidak terjadi hal-hal yang tidak diinginkan karena KUA Kecamatan Purwaharja yang mempunyai tujuan untuk mempertinggi mutu perkawinan dan mewujudkan keluarga yang sakinah, mawadah dan warahmah.

\section{DAFTAR PUSTAKA}

Ali Hasan, 2003, Pedoman Hidup Berumah Tangga Dalam Islam (Jakarta: Siraja) M. Idris Rmulyo, 1974, Tinjauan Hukum Perkawinan (Jakarta: Grafindo Persada)

Arifin, Pedoman Pelaksanaan Bimbingan dan Penyuluhan Agama (Jakarta: PT, Golden Trayon Press, 1998)

Kementrian Pendidikan Dan Kebudayaan, Kamus Besar Bahasa Indonesia,(Jakarta:Balai Pustaka, 1994)

Wahbah Al-Juhaili, Al-Fiqh Alislami Wa Adilatuh (Beirut: Dar Al-Fiqr, 1989) 
Kompilasi Hukum Islam, Dasar-Dasar Perkawinan (Jakarta: Kencana, 2007)

Tim Al Manar, Fiqih Nikah: Panduan Syar'I Menuju Rumah Tangga Islami (Bandung: Cipta Media, 2006)

Kamal Mukhtar, Asas-Asas Hukum Islam Tentang Perkawinan (Jakarta: Bulan Bintang, 1993)

Amir Syarifuddin, Hukum Perkawinan Islam Di Indonesia (Jakarta: Kencana, 2007)

Ali Hasan, Pedoman Hidup Rumah Tangga Dalam Islam (Jakarta: Siraja, 2003)

Zainuddin Ali, Hukum Perdata Islam Di Indonesia (Jakarta; Sinar Grafika 2006)

Sutrisno Hadi, Metodologi Research Jilid II (Yogyakarta: Penerbit Andi, 1987)

Suharsimi Arikunto, Prosedur Penelitian, Suatu Pendekatan (Jakarta: Rineka Cipta, 1993)

Lexy J. Moleong. Metodologi Penelitian Kualitatif (Bandung: Remaja Rosda Karya, 2000)

Mattew B. Milles dan A Michael Huberman, An Expanded Sourcebook Qualitative Analysis, Second Edition (New Delhi: Sage Publications, 1992)

Slamet Abidin dan Aminuddin, Fiqih Munakahat 1 (Bandung: Pustaka Setia) 